\title{
Tyrannous Minds and Tamed Bodies: The Curious Case of Irene Adler from Canon to Screen
}

\author{
Debanjali Roy ${ }^{1} \&$ Tanmoy Putatunda ${ }^{2}$ \\ ${ }^{1}$ Assistant Professor, School of Languages, KIIT Deemed to be University, \\ itsmeanjee@gmail.com, https://orcid.org/0000-0002-2496-6091 \\ ${ }^{2}$ Assistant Professor, School of Languages, KIIT Deemed to be University, \\ tanmoy.putatunda@gmail.com, https://orcid.org/0000-0002-9698-9487
}

\begin{abstract}
Appearing in the singular short story "A Scandal in Bohemia" in Sir Arthur Conan Doyle's Sherlock Holmes series, the character of Irene Adler has been adapted and reconstructed in subsequent literary and visual media. Twenty-first century screen adaptations have swivelled upon postfeminist re-appropriations of the character and overt sexualisation of the 'body', thereby engaging in reassessment of the Irene-Sherlock relationship and problematizing gendered presentations of the character. Locating Irene in a heteronormative space, such narratives have attempted to revise the image of the cross-dressing 'adventuress' through varied portrayals which seemingly broaden her scope by means of her deliberate transgressions of fixed gender tropes. This article, by taking into account the gendered power-play embedded in three popular twenty first century screen adaptations of the text, namely, the films Sherlock Holmes (2009) and Sherlock Holmes: A Game of Shadows (2011), CBS's Elementary (2012-2019) and BBC's Sherlock (2010-2017), scrutinizes the dilemma of presentation of Irene Adler through the lenses of sexual dynamics and gendered performances.
\end{abstract}

Keywords: Gender dynamics, Sexuality, Body, Subversion, Adaptation, Performances, Identity

\section{"Women don't fit well into a trench coat and slouch hat"}

Probing into the politics of representation of women characters in detective fictions and commenting on "feminist rewritings" of the genre, Anne Cranny- Francis in the essay Gender and Genre: Feminist Rewritings of Detective Fiction, had quoted this 1985 remark by crime fiction writer Lawrence Block: "Women don't fit well into a trench coat and slouch hat"- a comment that aptly summarises the tradition and rationale behind peripheralising women characters in the phallogocentric domain of detective fiction. Noting how the detective figure is essentially a "cynical loner, a man at odds with society and its values... not something women normally relate to" (Cranny-Francis, 1988, p.69), Block was representing not only the binarism and gendered notions of roles that men and women are supposed to play within the society, he was also embodying the uber masculine gaze through which women are seen and portrayed in detective fictions (Cranny-Francis, 1988, p.69). Although Block's comment was embedded in his

This Open Access article is published under a Creative Commons Attribution Non-Commercial 4.0 International License (http://creativecommons.org/licenses/by-nc/4.0/), which permits non-commercial re-use, distribution, and reproduction in any medium, provided the original work is properly cited. For citation use the DOI. For commercial re-use, please contact editor@rupkatha.com. 
understanding of contemporary American culture where the "hard boiled private eye" was equated with the masculine American identity perpetuated through popular detective fiction of the time, the canonical detective stories which garnered huge popularity in the nineteenth century England were equally enmeshed in the phallogocentric perspective (Stasio, 1985).

Detective fiction in England started around late 1840s, with the setting up of the detective department in Scotland Yard in the year 1842 (Griffin, 2015, p. ii) and contained very few 'active' women characters, mirroring the expectations and realities of the "angel in the house"- the domesticated status of women. However, much like the socio-political realities of the women, the genre too shifted its perspectives in representing and accommodating women with prominence in its domain. Catalyzed by "The New Aspect of the Woman Question" (Ledger, 1997, p. 9) and the "New Woman" foraging into art and literature of the fin de siècle, there was a marked decrease in "the use of female characters as solely victimised presences in narratives to portray social commentary in the era" (Saunders, 2015, p. 60-63). Sir Arthur Conan Doyle's stories represent a trend in the genre of detective fiction that marks the transition in the portrayal of women characters from vulnerable, passive and fringed to a more nuanced depiction, a trend that casts women in diverse roles that include clients, victims, witnesses and even criminals. However, despite this move away from conventional portrayal of women characters, the fictional world in Doyle's Sherlock Holmes narratives could not escape the masculinist trappings of valorising the detective who is almost always male and represents masculinity, reason, rationality and order. Therefore, it is of little surprise that by deliberately limiting the possibilities of women characters like Irene Adler, Mary Morstan and Mrs. Hudson, Sherlock Holmes was in fact, consolidating, supporting and establishing the image of the male detective as the undisputed champion of intellect, wit and heroism. This systematic masculinisation of the narrative not only secured the character of Sherlock Holmes as an 'archetype' for Victorian detective figures, but also fostered subsequent readings and interpretations of the text through literary and visual adaptations notably marked by the exploration of sexuality (or asexuality) of the detective and his sexual dynamics with the women characters in the stories.

A curious trend with these postmodern readings have been an increased focus on the character of one Ms. Irene Adler and experimentations and reconstructions of her character visà-vis Holmes's identity formation. Despite appearing only in one story ("A Scandal in Bohemia") in the canon, unlike the other women characters, she has received maximum attention in exploration of Holmes's dynamics with women characters in the contemporary adaptations of the text in visual media and these adaptations too, have mostly focused on her "body" and physical representation by hinging on tropes of sexuality. Encashing the subversive possibilities in Doyle's sketch of Adler's character, twenty first century screen adaptations have almost always attempted a post-feminist metamorphosis by providing her apparent autonomy over her body where she can manoeuver her sexuality to exert control over the male-centred narrative. Such metamorphosis, as this article argues, is problematic in nature as by "sexing up" her character, the show-creators have failed to re-appropriate the character from its Victorian original by falling back on dominant masculinist discourses. (Primorac, 2018, p. 28-33). This article thus, through a close reading of three contemporary screen adaptations of Sherlock Holmes, namely, the films Sherlock Holmes (2009) and Sherlock Holmes: A Game of Shadows (2011) by Guy Ritchie, the television series Elementary (2012-2019), and BBC's Sherlock (2010-2017) vis-à-vis the canon, attempts to 
substantiate that despite efforts to empower the character of Irene Adler by providing her apparent autonomy and agency within the masculine gaze by subversive treatments and portrayals, these shows fail to debunk or invert conventional gender politics.

\section{The man, the woman and the detective}

The ambiguous gendered discourse is present in the canonical treatment of Holmes-Adler relationship as well. "A Scandal in Bohemia", the first short story in the Holmes series, published in 1891 begins with the description of Irene Adler in the narrative voice of Watson: "To Sherlock Holmes she is always the woman. I have seldom heard him mention her under any other name. In his eyes she eclipses and predominates the whole of her sex" (Doyle, 1992, p. 117). What is interesting yet problematic about such an introduction is the way it serves as a prelude to the curious treatment of gender identities- identities that are performed, malleable and mutable in nature. What Watson writes about Adler is not his estimation of her character but rather an articulation of the views of Sherlock Holmes and how this particular woman "eclipses" Holmes's opinion about other women of his time. This description, while identifying Adler as unique and markedly different from other women, also upholds the conventional notions of womanhood as perceived by the Victorian male detective and narrated by a male mouthpiece of a Victorian male novelist for the Victorian audience who had stereotypical ideas concerning the woman and what womanhood entails.

In most of the short stories in the Holmes series, women were sketched from conventional, fixed ideas of femininity, ones that mirrored the limited scope and roles of women in contemporary society and their lack of agency. What distinguishes the portrayal of Adler from these women characters is her social-sexual identity, one that defies distinct categorisations of gender identity by virtue of her subversions of defined, stereotyped gender roles and performances. Called "a well-known adventuress" by her former lover, the King of Bohemia (Doyle, 1992, p. 121), Irene is a retired opera artist, whom conventional Victorian assumptions would label as "an unscrupulous woman seeking social or financial advantages through questionable, often sexual, means"; a classification that highlights her "liminal position" between gendered and social binaries. She is an embodiment of the features of the "the New Woman Criminal" - a figure that problematised the Victorian binaries of "angel in the house" and fallen woman by representing "a specifically public form of femininity for a culture that was redefining and redistricting "public" and "private" amid modern social change" (Miller, 2008, p. 3). This fluidity in the essence of the character, "offers an endless destabilization and disruption of what seems fixed", one that renders Irene inscrutable to the visual deductions (Gray2003, as cited in Miller 2008, p. 41) of the male detective. (Gray, Frances. Women, Crime and Language. Houndmills, Hampshire: Palgrave, 2003. Cited in Miller).

The story of "Bohemia" revolves around how Holmes is employed by the King who is about to marry a Scandinavian princess. The king is however worried because of his past secret relationship with Adler who possesses a photograph of herself and the king together. As the king has failed to retrieve the photograph despite his multiple attempts, he now wants Holmes to help. With the help of disguise and deceit, Holmes identified the place where Irene hid the photographs. 
Surprisingly, Irene outwits Sherlock in his own game of disguise and deceit, and flees with the photographs leaving a photograph of herself and a letter addressed to Holmes. Reading Adler's disguise as a suggestion that "outward displays of gender can be manipulated and faked: visual markers of gender are not a "natural" expression of innate subjectivity", Miller underlines Holmes' failure due to his reliance on "visual means of knowledge", one that is challenged by Irene. His failure to identify Irene as the "slim youth in an ulster" (Doyle, 1992, p. 129) not only foregrounds an active subversion of Holmes' normatively gendered understanding but also results in the usurpation of his authority as the dominant male figure in the narrative- authority that is mostly located/ pronounced by his gaze (Katzir, 2015, n.p.). In "Performative Acts and Gender Constitution: An Essay in Phenomenology and Feminist Theory", Judith Butler notes, "if gender is instituted through acts which are internally discontinuous, then the appearance of substance is precisely that, a constructed identity, a performative accomplishment" (Butler, 1988, p. 520). Unlike Mary or the other women characters who 'perform' predefined roles, Irene poses a challenge to the patriarchal status quo not just by diluting the gender roles by masquerading as a man and 'beating Sherlock Holmes in his own game', but she also threatens the sanity of Holmes by disrupting his aura of cold rationality and emotion-less-ness, traits usually associated with masculinity. Irene is able to deceive the detective by cross-dressing, by playing on the gendered assumptions of femininity and womanhood by Sherlock with her gender performances; an act that interestingly complements Sherlock's own transgressing of established notions of Victorian masculinity and equates them in the great game of performance.

Though critics have evaluated this portrayal of Adler as "proto-feminist: a strong female character who was just as smart as the smartest man" (Rocha and Rocha, 2011, cited in Taylor, 2015 , n.p.), it is difficult to ignore how the narrative attempts to balance or restore 'order' through ameliorating the gendered transgression by sanctifying the "adventuress" into domestic tropes of matrimony and is also made to leave the country thus removing the 'dangerous' presence in the detective's life. This is attested by the final act of Holmes keeping the portrait of Adler and Watson's observation that whenever Holmes speaks about Adler "or when he refers to her photograph, it is always under the honourable title of the woman" (Doyle, 1992, p. 131). Reading Holmes' treatment of the photograph along Bazin's philosophy of images that claims: "photographic image is the object itself" (Bazin, 1945, "The Ontology of the Photographic Image", p. 14 cited in Miller, 2018, p. 42), Miller notes how the photograph becomes a "surrogate" for Adler herself and thus, for Holmes, acquiring the photograph stands as a substitute for possessing Irene- an act that can compensate for his defeat and restore a semblance of equilibrium in his deranged world.

This ambiguous treatment of an apparently emancipated woman and her relationship with the eponymous detective 'hero' have presented a tempting playground for experimentations and reworkings in visual media, especially in recent decades. By several permutations and combinations in the semiotic arrangement, attempts have been made to make Adler more autonomous, more active, challenging and threatening the masculine world of Holmes. Ironically however, instead of liberating the character from the patriarchal notions of normativity, these representations, by metamorphosing Adler from cerebral to physical and ascribing the agency of power around the masculinist notions of sexuality, have not only moved away from the canonical 
construction of Adler's character whose power lay in her wit but also have associated sexuality with criminality.

\section{"She solved you"}

Interestingly, in CBS's Elementary, Irene Adler is not only a seductress who seeks to exploit Holmes in order to serve her own agenda, but also is the criminal mastermind and Holmes's arch-nemesis. The portrayal of Irene Adler in this series is more complex as opposed to other visual adaptations in the sense that it deconstructs the canonical narrative from multiple points. Adler here is not a 'real character' but her identity is created by Jamie Moriarty (played by Natalie Dormer) who is reminiscent of the canonical male adversary of Holmes, Professor Moriarty.

Holmes (played by Jonny Lee Miller) is a recovering drug addict and unequivocally heterosexual. He notes in the very beginning of the series, "I actually find sex repellant, all those fluids and all the sounds, my brain and my body require it to function at optimum levels- so I feed them as needed" ('Pilot'). This sexualized presentation of the detective prepares the ground for exploring a heterosexual, romantic relationship of Holmes with Adler, a presentation that characterises almost all other "non-canonical presentations" and adaptations of Sherlock Holmes (Taylor, 2015, p. 58).

Sherlock gives us the first elaborate glimpse into the nature of his relationship with Irene in the episode titled ' $M$ ', where he is reunited with a "serial killer" who he assumes, had claimed the life of his beloved Irene. Admitting to Watson (played by Lucy Liu) that he was in fact, quite "smitten" by her and until that episode in his life, he "had found most women boring ...a perfumed and pillowy means to a physiological end. Irene was different", the show's Sherlock echoes Holmes' opinions in Doyle's narrative (M). However, this is a different game- not just a game of disguises and charades and role playing but one that interrogates and blurs the boundaries of reality and illusion. Although Holmes is led to the 'knowledge' about Moriarty from the assassin M/Sebastian Moran (whom he corners on account of his belief that Moran is the killer of Adler) through the conventional techniques of detective fiction, by the end of the episode, he realises that there is a greater "puzzle" at work which interestingly doesn't involve his agency and methods of deduction. In this modern spin-off directed by Robert Doherty, Moriarty reveals herself to Holmes while saving him from an assassin thereby shifting and altering conventional notions of agency and autonomy associated with gender roles. Overturning hierarchical ideas of gender roles, she not only claims agency and 'emasculates' Holmes by making him an object of her 'study' but also, by conjuring the image of a certain Irene Adler with whom Sherlock gets romantically involved, she initiates the free-play of endless signification by deferring the fixed gendered identity of the detective. At the end of the episode, the agenda of rewriting hierarchical assumptions of gender binaries is highlighted when, exasperatedly, Sherlock asks: "So you're saying we're the same," she retorts back saying "I'm saying I'm better"('Heroine'). She explicitly disguised her gendered identity in the use of the word 'men', which is a subtle nod to Irene's gendered autonomy. Fooling Holmes for months, Adler/ Moriarty had entrapped Sherlock in his own game of disguise and when she returns to his life, Sherlock remains unaware of the fact that Irene is Moriarty or rather, Irene is a creation by Moriarty. By falling in love with Irene, the 
heterosexual Sherlock, with his knowledge of the female body and gender performances, failed to comprehend the mind of the woman, distinguish the unreal from the real. Unlike the Victorian series that established the masculine figure of Professor Moriarty as the adversary of the eponymous detective, Elementary eludes the 'persona' of Moriarty by encoding it into a female body making it difficult for the masculine mind of the detective to decode it with his deductive logic. Joseph Walker observes, "In Elementary, Moriarty is dangerous precisely because Holmes is drawn to her, and to what she represents: the opportunity to act with true autonomy and individual freedom in a world now dominated by the collective logic and conventional values of the procedural" (Walker, 2015, p. 165). This explains why the detective, entrenched in preconceived notions of identities and gender roles, cannot comprehend and rationalise the fluidity of identities embodied/disembodied by Jamie Moriarty.

However, this 'feminine' dominance encashing the illusory quality of the propagated image and the autonomy over the image and the body is stamped out when the narrative of the show falls back on predominant tropes - the trope of making the female 'nemesis' fall in love with the male detective that renders Holmes an unexpected and undue advantage in the 'game'. Therefore, the apparent liberation of gendered spaces, celebration of identities beyond gendered bodies is short-lived, as the narrative gradually adopts the familiar modus operandi of trapping the female body in the masculine gaze. Holmes starts doubting Adler only when he finds the mole on her back missing ('The Woman'). Despite the seemingly autonomous portrayal of Moriarty/Adler in the series, one of the glaring discrepancies lie in how the character seems to embody certain stereotypical, male-centric perspectives in her personal notions of womanhood as a result of which she unequivocally underestimates women. In Elementary, as in Doyle's story, Irene adopts the disguise/ identity of a man but here, her purpose is more complex. Explaining the reason to maintain the shadowy identity of a man, Moriarty tells Holmes that this serves her not only to protect her identity, but also "because I [Moriarty] suspected a potential client might struggle with my gender. As if men had a monopoly on murder" ('Heroine'). All of her associates in crime whom she calls 'lieutenants' are also men. Jessica Seymour argued that in Elementary,

Moriarty has internalised the patriarchal expectations of gender identity in the Western world. While Moriarty is arrogant - telling Holmes that she is better than him, and that he is a game she will win every time - she acknowledges that a potential client might 'struggle' with her gender ('Heroine' 1.24) and takes steps to hide it. (Seymour, 2015, p. 8)

Moriarty also presumes that Joan Watson is engaged in a romantic relationship with Holmes rather than being a professional partner. Thus, to some extent, despite utilising the advantageous understanding of gender fluidity in her actions against Sherlock, Moriarty's perceptions resort to gender stereotypes shaped by patriarchy. Adler/ Moriarty's underestimation of women, her dismissive attitude towards Watson proves to be her fatal flaw thereby reestablishing the failure of the series to venture beyond habitual understanding of gender identities. There is an attempt to reverse the roles in Watson decoding her instead of Sherlock which is also acknowledged by Moriarty when she tells Watson, "If you weren't I would never have been caught". However, at the end, she is the puzzle that is finally "solved". ('The Diabolical Kind')

Positing Moriarty/Adler under the 'diagnosis' by Watson, the series does in fact apparently overturn the male hegemony over the science of deduction, but by elevating Holmes from her 
object of study to be her weakness, one that costs her own freedom, is symptomatic of the trend of "criminalising" the character of Irene Adler across adaptations (Douglas n.d.). At one level, both Holmes and Adler/ Moriarty act as each other's tragic flaw. Only difference being that for Holmes, the moral universe is rigid and he is not reluctant to use Adler/ Moriarty's weakness for him as a trap in order to hand her over to the police. He even celebrates triumphantly saying "my nemesis has been defeated" ('Heroine'), articulating the reinstatement of order in the Holmesian world.

\section{"Everyone has a weak spot, and he found mine"}

Guy Ritchie's Sherlock Holmes films are quite straightforward in positing Irene Adler as Holmes's love interest. In doing so, as Antonija Primorac also notes, it places itself within a long tradition of such "afterings" like "the TV film Sherlock Holmes in New York (1976), the fictional biography of Sherlock Holmes by William Stuart Baring-Gould, Sherlock Holmes: A Biography of the World's First Consulting Detective (1962), John T. Lescroart's novel Son of Holmes (1986) or The Language of Bees (2009) by Laurie R. King" (Primorac, 2018, p. 37). In both the films, Sherlock Holmes (2009) and Sherlock Holmes: A Game of Shadows (2011), Irene Adler assumes authority through her sexuality. This 'empowerment' is problematic because it is defined and shaped through the 'male gaze' and derives its meaning only within the patriarchal structure of agency and control. As opposed to Doyle's narrative that grants her autonomous agency, Irene, in this adaptation, works under Moriarty and lacks any independent motive and purpose. Following the instructions of the male criminal mastermind, she weaponises her sexuality to trap the male detective- all the while functioning as a mere pawn, an intellectual inferior in comparison to the male characters.

Unlike Elementary, where Adler's power lies in the image that she crafts for the detective's consumption, here, Adler's power is mostly equated with the clothing or the absence of it. One of the most obvious instances of display of this power is in the hotel room scene of Sherlock Holmes (2009) when Irene (played by Rachel McAdams) effectively uses her sexual allure by dressing in front of Sherlock (played by Robert Downey Jr.), kissing him passionately and drugging him, leaves him handcuffed to the bed, naked. Rhonda L H Taylor observes:

Her overt sexuality is a weapon used with the intent and result of disorienting Holmes and making him appear foolish, an emasculating (sic.). This Adler uses her female nudity as a disguise/deception to best Holmes, rather than assuming the canonical Adler's disguise as a young man to accomplish the same goal" (Taylor, 2015, p. 71)

However, despite momentary episodes where she seemingly enjoys authority by virtue of the politics of her concealed/naked body, most of the narrative of both the films work in employing her merely as a passive substrate for discharge of masculine energy. The phallic undertone in the observation is complemented by the fact that in the film (2009), Holmes and Watson actually 'rescue' Adler from a giant saw blade - a symbolic enactment of a man rescuing the woman's body from phallic threats, a silent nod to the Victorian ideas of womanhood. This 'rescue' is followed by Holmes uncuffing Irene, bringing to light the role of the handcuff as an agency of limiting movement and potential. Towards the end of the movie, after saving Adler, Holmes handcuffs her, mirroring the act of the hotel room scene and implying that it is Holmes now who is in control of her body. The act of sanctifying volatile female sexuality by masculine agency is furthered when 
after handcuffing Adler, Holmes also leaves the key with her making him not only the man to rescue her, but one who is now in control of her life and can decide whether he wants her alive or dead.

With the narrative escalating towards the central conflict between Moriarty and Sherlock, Irene's death at the very beginning of the sequel, $A$ Game of Shadows (2011) in the hands of Moriarty, is inevitable. It serves to remove the potential threat, by virtue of her emotions and sexuality, of dismantling the rational and moral stability of the male-dominated narrative. Thus, Adler's appearance as a sexualized femme fatale followed by her defeat and death serves the purpose of establishing Holmes's heterosexuality, consolidating his intellectual and moral high ground and removing the possibility of any future threats that she might possess. Once her purpose in the Holmsian narrative tinged by heteronormativity and masculine trappings is fulfilled, she is effectively suppressed, abandoned and wiped out of existence. In Doyle's "Bohemia", Watson had noted: "It was not that he (Sherlock) felt any emotion akin to love for Irene Adler" (Doyle, 1992, p. 117). Departing from the canonical text, these films play with the possibilities of a romantic chemistry between Adler and Holmes. However, because Holmes and Adler situate themselves in the opposite poles of the moral universe, the possibility does not turn into reality. The canonical Adler's persuasion of justice has been turned into criminality. Watson asks Holmes, "Why is the only woman you've ever cared about is a world-class criminal? Are you a masochist?" Watson also reminds Holmes that, "She's [Adler] the only adversary who ever outsmarted youtwice. Made a proper idiot out of you." (Sherlock Holmes, 2009). In this observation, there seems to be an implied indictment that Holmes needs to avoid being 'idiot' in future. In order to nullify the threat, he must defeat Adler.

\section{Locked and 'Sher-locked'}

One of the most controversial depictions of the character in contemporary visual media, the naked body of the lesbian dominatrix in the BBC's Sherlock series is at the centre of an array of theoretical explorations that scrutinises the postfeminist portrayal of Ms. Adler. Introduced in the episode titled 'A Scandal in Belgravia' (2012), the portrayal of Irene Adler attempts to underline the politics of gender and power in the highly sexualised body. Even before her identity is divulged to the audience, the camera attempts to establish her femininity by focusing on her "red fingernails and dainty ring" (Turner, 2015, p. 39).

In the adaptation by Moffat and Gatiss, the relationship between Irene and Sherlock hinges on the "body" which serves as a nexus of interconnected ideas pertaining to sexual identities and gender roles. Complementing the portrayal of Sherlock (played by Benedict Cumberbatch) in the beginning of this episode where he appears in his bed sheet, the many dressings and undressings of Irene in the domain of this episode attempt to explore the issues of identity and sexuality through the lens of disguise and role-plays. Contrasting Doyle's Adler who by virtue of being in the profession of acting, is adroit in using disguises to serve her purpose, BBC's Irene (played by Lara Pulver), detests the idea as she informs Sherlock who fails to 'read' her through the screen of her naked body, "the big problem with a disguise ... [is that] ... however hard you try, it's always a self-portrait" ("A Scandal in Belgravia") (Turner, 2015, p. 39). In continuation with contrasting the use of 'disguise' by Doyle's Adler and the Adler of Sherlock, it can be observed that while Doyle's 
Irene chooses to embrace a distinct masculine identity by cross dressing as a man, the "nakedness and purloining Sherlock's clothes" exhibited in the BBC version "presents a far more complex series of revelations that are centered around a desperation to keep her secrets. By the time both women have shed their masks it is clear who comes out on top: she who is willing to embrace the disguise as a self-portrait reaps its benefits, while she who tries to use self-reflection as a means of hiding from the world ultimately fails." (McCain, 2015, p. 111)

This overtly sexualized approach seems to benefit Sherlocks Irene initially as Sherlock, dressed as a bleeding vicar, actually fails to deduce anything whatsoever from her naked body. The naked body - which she calls her "battle dress- paradoxically proves to be the most effective disguise for her. Indeed, Irene continuously cites instances she holds sway over others using sexuality. When asked about her source of knowledge, more often than not, her answer is "I know what she/ he likes" ('A Scandal in Belgravia'). Moreover, after overpowering Sherlock by injecting him with sleeping drugs, she literally 'beats' him with the riding crop to snatch her phone away from Holmes. This beating with the riding crop is reminiscent of the first episode of the Season 1 where Sherlock beats a dead body with a riding crop that serves as one of his experiments. In getting beaten with a riding crop by Irene, not only is Sherlock's introductory act in the series mirrored but also there is a juxtaposition of gender hierarchies in its conventional sense. Sherlock is the one who is acted upon and Irene seems to be the active agent. However, the riding crop as a tool of her profession also bears references to sex and body and how fixed identities are construed in the estimation of the body. What apparently seems to be an act of autonomy thus gets reduced to a return to the tropes of gender. The narrative cannot help but imply the intellectual inferiority of "The Woman" (which ironically is the "professional" identity of Irene in this series) who, unable to beat Sherlock with her brain, overpowers him physically. The emphasis on the body in this episode reaches its climax when it is revealed that the passcode required to open the safe is actually her body-measurements.

Maria Alberto, in her essay "'Of dubious and questionable memory": The Collision of Gender and Canon in Creating Sherlock's Postfeminist Femme Fatale" argues that this sexualised depiction of Irene Adler in Sherlock posits her somewhat as a postfeminist femme fatale by arguing that,

...the postfeminist femme fatale type references the femme fatale's commercialization as it emphasizes the trappings of femininity and sexuality to disguise narrative function as agency... the postfeminist femme fatale type also falls short of the mark since she is not structurally valuable for herself. Whatever motives, beliefs, or actions this type might display, the agency behind them is the narrative's rather than her own: she is only female so that the male protagonist(s) can move forward, usually without her. (Alberto, 2015, n.p.)

Indeed, the power Irene Adler possesses as a seductress, temptress and dominatrix is proved to be temporary and she is soon shown to be dependent on Moriarty's assistance. She says, "I had a bit of help. Jim Moriarty sends his love. I had all this stuff, and never knew what to do with it. Thank God for the consulting criminal" ("A Scandal in Belgravia"). Even till this point, Irene was still dictating terms to Mycroft (played by Mark Gatiss) while Sherlock is left literally at the fringe of the discussion as well as the frame of the camera and evidently out of control of the proceedings. This uneasy situation is soon remarkably replaced with the restoration of Sherlock's masculine 
domination, as he breaks the passcode of the phone that Irene had equated with her "life" all through the episode. He 'decodes' her, by deducing her emotions with his cold rationality, in a classic return to encasing the autonomy of the woman within masculine boundaries. Stripped of her autonomy and 'Sher-locked', in tandem with the other adaptations of the Victorian character, Irene is no longer a threat to the sexuality/rationality of Sherlock (sexuality of the male detective has been a point of discussion in multiple episodes of this series) and can be safely removed from the 'system'. Interestingly, Steven Moffat, the co-creator of the series, has asserted in an interview to The Guardian that "in the original, Irene Adler's victory over Sherlock Holmes was to move house and run away with her husband. That's not a feminist victory" and maintained that in his adaptation "...Irene wins. When Sherlock turns up to save her at the end it's like Eliza Dolittle coming back to Henry Higgins in My Fair Lady: 'OK, I like you, now let me hack up these terrorists with a big sword.'" (Jeffries, 2012).

However, this section argues that the series, despite deviating from conventional depictions of Victorianism in its choice of setting and placement of characters, ends up affirming the regressive gender ideals- the woman's body has to be 'saved' and sanctified by the man- as at the end, the hijab-clad Irene is fittingly saved by Sherlock from the hands of a terrorist cell in Karachi, Pakistan. In the essay "Postfeminism and Screen Adaptations of Sherlock Holmes Stories: The Case of Irene Adler", Antonija Primorac observes,

By the end of the episode, the dangerously sexual female nude body of the metropolitan centre is displaced into a Pakistani desert and transformed into a kneeling powerless bundle of indigo-blue wraps that set off her tear-sodden face. The luminous skin of her 'battledress', of the naked female body-as-weapon, is supplanted by a crestfallen figure in a hijab. In a stereotypically Victorian fashion that does not feature in Doyle's text, Adler's use of her own body as a means of power turns her into a fallen woman who has to be punished, banished to the former colonial space and saved by the hero. (Primorac, 2018, p. 44)

And the hero gets to have complete authority over the woman; in this case, the episode ends with Sherlock keeping the mobile phone of Irene Adler, one that stamps his authority over her identity. In the words of film critic Jane Clare Jones, "the woman Holmes referred to as "the woman" was remade by Moffat as a high-class dominatrix saved only from certain death by the dramatic intervention of our hero. While Conan Doyle's original is hardly an exemplar of gender evolution, you've got to worry when a woman comes off worse in 2012 than in 1891" (Jones, 2012).

\section{"And this is just losing..."}

Elaine Showalter (1990) in her Sexual Anarchy characterizes the Victorian fin de siècle as a period "when all the laws that governed sexual identity and behavior seemed to be breaking down" and argues that marginal figures "redefined the meanings of femininity and masculinity" (p. 3). Written during this phase, Doyle's Sherlock Holmes series attempted to capture the rapidly changing connotations and definitions of gender identities by positing the female characters around the eponymous male character. Such depiction was unique in its own way as just like the marginal female figures he encounters, Sherlock too inhabits the social fringe by virtue of his debunking of codes that defined conventional gendered and social identities. However, such transgressive acts of the opium-addict detective were largely based on his inability to deduce any meaning out of 
such ritualistic identity formation similar to his inability of perceiving the workings of women's minds. Although this prevented the Holmesian canon from incorporating more powerful female characters within the narrative, it also created space for the fallibility of the detective which makes the character of Sherlock Holmes more realistic and closer to life. Intelligence and cleverness of Irene Adler in "A Scandal in Bohemia" not only made Holmes aware of his limitations, but also changed his perceptions of women in general. Watson notes, "He [Holmes] used to make merry over the cleverness of women, but I have not heard him do it of late" (Doyle, 1992, p. 131).

Unfortunately, as this article has argued, contemporary screen adaptations, despite being drawn towards the subversive possibilities of the character of Irene Adler and dedicating much critical and creative impetus in shaping the character, have invariably dismantled the insolubility and mystery that is associated with the canonical Adler. Despite its own limitations, while Doyle's narrative allowed Adler to elude Holmes's paradigm of rationality, twenty-first century screen adaptations have been keen to 'solve' her rather than letting her thrive in mystery. Therefore, while the text still celebrates the slippery nature of the gender dynamics characterising Irene- Holmes relationship, the screen adaptations have tended to remould Irene into a seductress, temptress and unequivocally criminal which inevitably necessitates either bringing her within the phallogocentric order by turning her into a damsel to be saved by the detective, and/ or meting out punishment in the name of restoring law and order. Subsequently, her bodily threat is required to be removed from the Holmesian world so that she can no longer pose sexual or intellectual threat to the detective-hero thereby restoring his monolithic authority in the gendered politics of power.

\section{References}

Alberto, Maria. (2015). Of dubious and questionable memory" : The Collision of Gender and Canon in Creating Sherlock's Postfeminist Femme Fatale. In Nadine Farghaly (Ed.), Gender and the Modern Sherlock Holmes: Essays on Film and Television Adaptations Since 2009. McFarland \& Company, Inc., Publishers

Butler, J. (1988). Performative Acts and Gender Constitution: An Essay in Phenomenology and Feminist Theory. Theatre Journal, 40(4), 519-531. https://doi.org/10.2307/3207893

Cranny-Francis, A. (1988). Gender and genre: Feminist rewritings of detective fiction. Women's Studies International Forum, 11(1), 69-84. https://doi.org/10.1016/0277-5395(88)90008-8

Doherty, R. (Writer), \& Polson, J. (Director). (2013). Heroine (Television series episode). In R. Doherty (Producer). Elementary. CBS.

Douglas, C. N. (n.d.). Why Can't They Get Irene Adler Right? Mystery Scene. Retrieved June 29, 2021, from https://www.mysteryscenemag.com/article/3237-why-cant-they-get-irene-adler-right

Doyle, A. C. (2019). The Return of Sherlock Holmes (100th Anniversary Edition): With 28 Original Illustrations (Illustrated ed.). SeaWolf Press.

Doyle, Arthur Conan. (1992). The Adventures of Sherlock Holmes. Wordsworth Classics.

Gatiss, M. (Writer), \& Lovering, J. (Director). (2012). A Scandal in Belgravia (Television series episode). In S. Vertue (Producer), Sherlock. BBC Worldwide.

Griffin, Rachael. (2015). Detective Policing and the State in Nineteenth-century England: The Detective Department of the London Metropolitan Police, 1842-1878 (Doctoral dissertation). The University of Western Ontario. https://ir.lib.uwo.ca/etd 
Jeffries, S. (2012). "“There is a clue everybody's missed": Sherlock writer Steven Moffat interviewed". The Guardian. https://www.theguardian.com/tv-and-radio/2012/jan/20/steven-moffat-sherlock-doctorwho

Jones, J. C. (2012). "Is Sherlock sexist? Steven Moffat's wanton women." The Guardian. https://www.theguardian.com/commentisfree/2012/jan/03/sherlock-sexist-steven-moffat

Katzir, Lindsay. (2015). I Am Sherlocked: Adapting Victorian Gender and Sexuality in "A Scandal in Belgravia". In Nadine Farghaly (Ed.), Gender and the Modern Sherlock Holmes: Essays on Film and Television Adaptations Since 2009. McFarland \& Company, Inc., Publishers

Ledger, Sally. (1997). The new woman: Fiction and Feminism at the Fin De Siecle. Manchester University Press.

McCain, K. (2015). "Feeling Exposed?": Irene Adler and the Self-Reflective Disguise. In Nadine Farghaly (Ed.), Gender and the Modern Sherlock Holmes: Essays on Film and Television Adaptations Since 2009. McFarland \& Company, Inc., Publishers

Miller, E. C. (2008). Framed: The New Woman Criminal in British Culture at the Fin de Siecle (Illustrated ed.). The University of Michigan Press.

Primorac, A. (2018). Neo-Victorianism on Screen: Postfeminism and Contemporary Adaptations of Victorian Women (Palgrave Studies in Adaptation and Visual Culture). Springer.

Ritchie, G. (Director). (2009). Sherlock Holmes. Warner Bros.

Ritchie, G. (Director). (2012). Sherlock Holmes: A Game of Shadows. Warner Bros.

Saunders, Samuel. (2015). Many Suitable Jobs for Women: Examining the Female Character in Victorian Detective Fiction (Master's Thesis, Liverpool John Moores University). Academia.edu. https://www.academia.edu/33767574/Many_Suitable_Jobs_for_Women_Examining_the_Female_Cha racter_in_Victorian_Detective_Fiction

Seymour, J. (2015) 'Holmes's Girls: Genderbending and Feminising the Canon in Elementary' 20th Annual AAWP Conference, Swinburne University, Hawthorne Campus, 29 November-1 December.

Academia.edu.

https://www.academia.edu/17947947/Holmes_s_Girls_Genderbending_and_Feminising_the_Canon_i n_Elementary

Showalter, E. (1990). Sexual Anarchy: Gender and Culture at the Fin de Siecle (First Edition). Viking.

Stasio, M. (1985, April 28). Lady Gumshoes: Boiled Less Hard. The New York Times. https://www.nytimes.com/1985/04/28/books/lady-gumshoes-boiled-less-hard.html

Taylor, R. L. H. (2015) Return of "the woman": Irene Adler in Contemporary Adaptations". In Nadine Farghaly (Ed.), Gender and the Modern Sherlock Holmes: Essays on Film and Television Adaptations Since 2009. McFarland \& Company, Inc., Publishers

Turner, B. (2015). There's a Name Everyone Says: Irene Adler and Jim Moriarty in Sherlock. In Nadine Farghaly (Ed.), Gender and the Modern Sherlock Holmes: Essays on Film and Television Adaptations Since 2009. McFarland \& Company, Inc., Publishers

Walker, Joseph S. (2015). The Woman and the Napoleon of Crime: Moriarty, Adler, Elementary. In Nadine Farghaly (Ed.), Gender and the Modern Sherlock Holmes: Essays on Film and Television Adaptations Since 2009. McFarland \& Company, Inc., Publishers

Debanjali Roy is working as an Assistant Professor in the School of Languages, KIIT Deemed to be University. She is pursuing her her Ph.D. in the Department of English, University of Calcutta. Her research interests include Sociolingusitics and English Language Teaching, Gender Studies, Modern Art and Litearture and Popular Literature 
13 Tyrannous Minds and Tamed Bodies: The Curious Case of Irene Adler from Canon to Screen

Tanmoy Putatunda is working as an Assistant Professor in the School of Languages, KIIT Deemed to be University. He is also pursuing his Ph.D. in the Department of English, Visva-Bharati, Santiniketan. His research interests include Urban Studies, Representation of City in Literature, Indian Literature in English, Popular Literature, Culture Studies, Postmodern and Postcolonial Literature. 